\title{
KDM5C wt Allele
}

National Cancer Institute

\section{Source}

National Cancer Institute. KDM5C wt Allele. NCI Thesaurus. Code C97599.

Human KDM5C wild-type allele is located within Xp11.22-p11.21 and is approximately 34 $\mathrm{kb}$ in length. This allele, which encodes lysine-specific demethylase $5 \mathrm{C}$ protein, plays a role in both histone modification and transcriptional regulation. Mutation of the gene is associated with JARID1C-related syndromic X-linked mental retardation and may be associated with clear cell renal carcinoma. 